удК 339.944:005.332.4

DOI https://doi.org/10.32851/2708-0366/2021.7.5

Лєгостаєва 0.0.

кандидат економічних наук, доцент кафедри міжнародного бізнесу та економічної теорії, Харківський національний університет імені В.Н. Каразіна ORCID: http://orcid.org/0000-0001-6753-3168

Liegostaieva Olena

V.N. Karazin Kharkiv National University

\title{
ВИЗНАЧЕННЯ КЛЮЧОВИХ ЧИННИКІВ ФОРМУВАННЯ МІЖНАРОДНОÏ КОНКУРЕНТОСПРОМОЖНОСТІ ВІтЧИзнянИх ПІДПРИємСтв
}

\section{DETERMINATION OF KEY FACTORS OF FORMATION OF INTERNATIONAL COMPETITIVENESS OF DOMESTIC ENTERPRISES}

\begin{abstract}
Статтю присвячено дослідженню міжнародної конкурентоспроможності підприємств Украӥни. Визначено п'ять основних інструментів для досягнення успіху на зовнішніх ринках. Обгрунтовано та запропоновано основні елементи для міжнародної конкурентоспроможності фірми Також зазначено, шчо для оцінки потениійного попиту на певні товари необхідно враховувати деякі чинники. Ринковий потенціал необхідно аналізувати, спираючись на такі змінні, як розмір ринку, темпи зростання ринку, інтенсивність ринку, ємність ринкового споживання, комериійна інфраструктура, економічна свобода, ринкова сприйнятливість. Запропоновано шість ключових чинників та заходи впровадження, за якими підприємства повинні формувати свою конкурентоспроможність задля ї̈ підвищуення на міжнародному ринку. Компанія, яка бажає зміцнитися на міжнародному ринку, повинна дотримуватися хоча б більшої частини запропонованих заходів. Чим більше компанія матиме конкурентних переваг, тим вище ї̈ конкурентоспроможність та ефективність на міжнародному ринку.
\end{abstract}

Ключові слова: міжнародна конкурентоспроможність, конкурентоспроможність, зовнішній ринок, чинники конкурентоспроможності.

Статья посвящена исследованию международной конкурентоспособности предприятий Украины. Определены пять основных инструментов для достижения успеха на внешних рынках. Обоснованы и предложень основные элементы для международной конкурентоспособности фирмы. Также отмечено, что для оценки потенциального спроса на определенные товары необходимо учитывать ряд факторов. Рыночный потенциал необходимо анализировать, опираясь на такие переменные, как размер рынка, темпь роста рынка, интенсивность рынка, емкость рыночного потребления, коммерческая инфраструктура, экономическая свобода, рыночная восприимчивость. Предложень шесть ключевьх факторов и меры внедрения, по которым предприятия должны формировать свою конкурентоспособность для ее повышения на международном рынке. Компания, которая желает укрепиться на международном рынке, должна соблюдать хотя бы большую часть предложенных мероприятий. Чем больше компания будет иметь конкурентньх преимуществ, тем выше ее конкурентоспособность и эффективность на международном рынке.

Ключевые слова: международная конкурентоспособность, конкурентоспособность, внешний рынок, факторы конкурентоспособности.

The article is devoted to the study of the international competitiveness of Ukrainian enterprises. There are five main tools for success in foreign markets. Competitiveness is often measured from the point of view of prices, characteristics of one product and the productivity of other competitors. It is also possible to vrahuvati the quality of the product as an indicator, which is even more important than the value of the product. The competitiveness is convinced and is guilty to bring the market to the full extent, the arrival of some of the most successful indicators of success. International competitiveness and the quality of companies competing on international 
markets. The basic elements for the international competitiveness of the firm are substantiated and offered. It is also noted that some factors need to be taken into account to assess the potential demand for certain goods. Market potential must be analyzed based on variables such as market size, market growth rate, market intensity, market consumption capacity, commercial infrastructure, economic freedom, market receptivity. Six key factors and implementation measures are proposed, according to which enterprises should form their competitiveness in order to increase it on the international market.In the current struggle for a place on the new markets, there is a shortage of victorious prices only for the prices of the bureaucrats. At the moment of opening and in the process of robotics, be it a promislova or a commercial company, it will face the problem of securing competitiveness in the current and international markets. The international competitiveness of any state sub'kta is formed from decilkoh passages, which appear on the international market for an additional introduction from the leading indicators of foreign companies-competitors. Therefore, it is necessary to actively promote the advancement of scientific and technical progress and improve the quality of products. It is necessary to realize that the company, as a bazhac change on the international market, is guilty after it wants to see more of the proponent calls. More companies will be able to compete with each other, and more competitively and efficiently on the international market.

Key words: international competitiveness, competitiveness, foreign market, competitiveness factors.

Постановка проблеми. Підприємства знаходяться у постійному пошуку конкурентних переваг, оскільки вони є основою їхньої діяльності, найбільш значущими чинниками конкурентоспроможності й основними визначальними елементами конкурентної позиції на ринковому сегменті. Успішне функціонування і розвиток підприємства в ринковій економіці вимагає виявлення й аналізу його конкурентних переваг. Міжнародну конкурентоспроможність можна визначити як процес, за якого високий рівень конкурентоспроможності можна досягти на різних рівнях (на фірмовому, регіональному та національному). При цьому конкурентоспроможність уважається міжнародною, коли вона стосується двох або більше країн. Такий процес охоплюється поняттями конкурентоспроможності, які переходять від загальної перспективи до більш конкретних розумінь на рівні фірм та країн.

Аналіз останніх досліджень і публікацій. Теоретичні, методичні та практичні аспекти міжнародної конкурентоспроможності підприємств досліджували зарубіжні та вітчизняні вчені, зокрема: О.В. Блідар [6], Д.О. Глущенко [1], А.О. Касич [1], О.В. Михайленко [2], К.Г. Орлова [2], І.В. Петрищева [3; 4], Д.С. Терехов [6], О.Г. Янков [7] та ін.

Але вивчення публікацій за даним напрямом свідчить, що сьогодні потребує подальшого дослідження та пошуку напрямів удосконалення міжнародна конкурентоспроможність вітчизняних підприємств. У зв'язку із цим дослідження з питань міжнародної конкурентоспроможності підприємств України набуває особливого значення, що визначає актуальність вибраної теми та доцільність проведення досліджень для розвитку цього питання.

Формулювання цілей статті. Метою дослідження є визначення та обгрунтування ключових чинників формування міжнародної конкурентоспроможності вітчизняних підприємств

Виклад основного матеріалу. Сучасні умови, в яких здійснюються бізнес-процеси в Україні, характеризуються впливом таких чинників, як політична ситуація, добросовісність конкуренції, невизначеність. Нині більшість суб'єктів господарювання здійснює діяльність в умовах обмеженої, неточної й мінливої інформації про стан середовища, в якому вони функціонують і розвиваються. Тому подолання невизначеності і зниження ризику є ключовими завданнями в рамках забезпечення життєздатності та досягнення високих конкурентних позицій сучасних компаній.

Міжнародна конкурентоспроможність суб’єкта господарювання включає цілу низку конкурентних переваг, які виявляються на світовому ринку завдяки зіставленню 3 відповідними показниками закордонних фірм-конкурентів. Із цього випливає, що 
чим більше у компанії набір конкурентних переваг і кращі їхні якісні характеристики, тим більше вона має сприятливих передумов для успішної діяльності на зовнішніх ринках, зайняття стійких позицій у його окремих сегментах.

Компанії дивляться на міжнародну присутність із багатьох причин. Найпоширенішими є вигоди від вступу на швидко зростаючі ринки та зменшення витрат. Однією 3 поширених причин прямих іноземних інвестицій є захист внутрішнього ринку.

Ще однією поширеною причиною є придбання технологічної та управлінської експертизи шляхом створення операцій поблизу діяльності провідних конкурентів. Також можуть бути й інші причини: щоб уникнути протекціоністських бар'єрів, отримати доступ до джерел конкретних ресурсів, прослідкувати конкуренцію, шукати можливості, скористатися запропонованими стимулами, створити економію на масштабі.

Конкурентоспроможність - це відносний термін, який можна інтерпретувати лише стосовно конкурентів фірми.

Конкурентоспроможність часто вимірюється з погляду ціни, собівартості одиниці продукції або продуктивності праці щодо конкурентів. Також можна врахувати якість продукції як показник, але ії важче визначити кількісно. Удосконалена конкурентоспроможність повинна призвести до поліпшення частки ринку, прибутку чи інших показників успішної діяльності.

Міжнародна конкурентоспроможність - це здатність фірми конкурувати на міжнародних ринках.

Можна виділити п’ять основних інструментів для досягнення успіху на зовнішніх ринках:

- місія, яка відображає прихильність до міжнародної ділової діяльності;

- здатність швидко ідентифікувати та пристосовуватися до потреб та можливостей споживачів;

- здатність розуміти поведінку споживачів у різних країнах;

- здатність розробляти та підтримувати високоякісну, конкурентоспроможну продукцію;

- хороший потенціал та програма для перевірки потенційних ринків та сайтів.

Визначальними елементами для міжнародної конкурентоспроможності фірми можна вважати такі:

1. Специфіка фірми та її основні переваги. Кожна фірма має свою специфіку, і деякі 3 них є унікальними. Компанії, які вдосконалюють свою діяльність, поступово розвиваються у справах, які вони роблять найкраще, і потім вони можуть бути використані як конкурентна перевага на міжнародних ринках.

2. Репутація. Через деякий час фірма, яка добре використовує свої специфічні особливості, може розвинути певну репутацію. Реклама сама по собі не може призвести до стійкої репутації, якщо компанія не має товару чи послуги, які б відповідали запитам клієнтів; однак це допомагає збільшити впізнаваність продуктів чи компаній серед споживачів. Для створення доброї репутації потрібен час, але ії можна швидко пошкодити, коли щось піде не так.

3. Постійні інновації. На багатьох ринках інновації є передумовою для міжнародної конкурентоспроможності. Це стосується, зокрема, спеціалізованих або високотехнологічних продуктів, а також таких послуг, де технологія та нові послуги відіграють важливу роль.

4. Структура фірми. Структура фірми, яка описує культуру компанії, може включати практику набору та просування в компанію, темпи плинності персоналу, обсяг несправних товарів, кількість скарг клієнтів, відносини компанії з постачальниками та іншими зовнішніми організаціями.

Для оцінки потенційного попиту на певні товари необхідно враховувати деякі чинники. На промислово розвинутих ринках інформацію, необхідну для оцінки ринкового 
потенціалу товару, легше отримати (дослідницькі агентства, такі як Euromonitor, надають звіти, що містять інформацію про конкурентів, загальні витрати на товар, важливі соціальні тенденції, обсяг роздрібного продажу та ринкові ціни на товар, потенційні можливості тощо). Ринки, що розвиваються, такі як Китай, Індія чи Бразилія, є дуже привабливими, оскільки мають велику споживчу базу та швидкі темпи зростання. Проте брак інформації може бути дуже важливою проблемою [7].

Ринковий потенціал необхідно аналізувати, спираючись на такі змінні:

- розмір ринку (це оціночний розмір загальної економіки (від загальної чисельності населення країни або кількості енергії, яку вона виробляє та споживає), менеджери можуть класифікувати країни від найбільших до найменших незалежно від конкретного товару);

- темпи зростання ринку (зазвичай вони отримуються шляхом оцінки приросту ВВП та споживання енергії та допомагають менеджерам зосередитися на майбутніх можливостях з огляду на розмір, а не на поточну ситуацію);

- інтенсивність ринку (вона оцінює купівельну спроможність ринку з урахуванням приватного споживання на душу населення та ВВП на душу населення за паритетом купівельної спроможності);

- ємність ринкового споживання (часто оцінюється на основі відсотка населення ринку середнього класу);

- комерційна інфраструктура (змінні можуть включати кількість телефонів, телевізорів, факсів або ПК на душу населення; щільність асфальтованих доріг або кількість транспортних засобів на душу населення та населення на роздрібну торгову точку);

- економічна свобода (ураховує державну торгову політику, участь держави у бізнесі, забезпечення прав власності та силу чорного ринку);

- ринкова сприйнятливість (менеджери можуть побачити, наскільки сприйнятливим $є$ ринок товарів з їхньої країни, дивлячись на кількість імпорту на душу населення на ринок із рідної країни та вивчаючи зростання або спад цього імпорту);

- ризик країни (оцінка загального ризику ведення бізнесу, включаючи економічні, політичні та фінансові ризики).

Сьогодні найбільш вірним шляхом підвищення конкурентоспроможності на міжнародному ринку є використання принципів сталого розвитку в усіх сферах підприємницької діяльності.

Можна виділити шість ключових чинників та заходи впровадження, за якими підприємства повинні формувати свою конкурентоспроможність задля ії підвищення на міжнародному ринку (табл. 1).

Від моменту створення й у процесі роботи будь-яка промислова або комерційна компанія стоїть перед проблемою забезпечення конкурентоспроможності на вітчизняному та міжнародному ринках. Міжнародна конкурентоспроможність будь-якого господарського суб'єкта формується з декількох переваг, які визначаються на міжнародному ринку за допомогою зіставлення з відповідними показниками закордонних компаній-конкурентів.

Численні дослідження довели, що серед українських компаній міжнародною конкурентоспроможністю володіють тільки зайняті в експортоорієнтованому сировинному секторі. Однак й їхні позиції на міжнародному ринку не завжди є стійкими, як у провідних транснаціональних організацій.

У боротьбі на міжнародних товарних ринках українські підприємства можуть використовувати цінові чинники. Нерідко з метою закріплення на міжнародному ринку компанії продають товар за демпінговими цінами. Але в довгостроковій перспективі дана політика має зворотний ефект, тобто призводить не до розширення ринку збуту і збереженню конкурентоспроможності, а до значного звуження частки на ринку або повного витіснення з нього. 
Таблиця 1

\section{Ключові чинники, за якими підприємства повинні формувати свою конкурентоспроможність}

\begin{tabular}{|c|c|}
\hline Чинники & Заходи впровадження \\
\hline $\begin{array}{l}\text { 1. Структурні } \\
\text { чинники }\end{array}$ & $\begin{array}{l}\text { використання оригінальних ідей, пошуку унікальної сфери діяльності або } \\
\text { випуск конкурентоспроможного продукту; } \\
\text { організаційна структура малих і середніх підприємств повинна грунтуватися } \\
\text { на базі струкури цілей з обов'язковим проведенням координаційної роботи } \\
\text { всіх співробітників по конкретному товару; } \\
\text { здійснювати комплекс робіт з уніфікації та стандартизації продукції, що } \\
\text { виготовляється, з метою впорядкування за типами, розмірами і видами; } \\
\text { відбираючи персонал; } \\
\text { необхідно приділяти увагу професійним і досвідченим кадрам, а також } \\
\text { створювати умови для просування, мотивувати і заохочувати на якісну й } \\
\text { ефективну працю, спрямовану на забезпечення конкурентоспроможності }\end{array}$ \\
\hline $\begin{array}{l}\text { 2. Ресурсні } \\
\text { чинники }\end{array}$ & $\begin{array}{l}\text { здійснювати регулярний аналіз конкурентного середовища, а також } \\
\text { контролювати кількість постачальників та їхню конкурентоспроможність; } \\
\text { постійно тримати під контролем ключові параметри ринку, щоб не } \\
\text { упустити можливості отримати найбільш якісну і вигідну з фінансового } \\
\text { погляду сировину; } \\
\text { на регулярній основі проводити детальні дослідження ринку, оскільки } \\
\text { в майбутньому економія ресурсів у споживачів товарів стоятиме на } \\
\text { пріоритетному місці; } \\
\text { на регулярній основі проводити функціонально-вартісний аналіз продукції, } \\
\text { що випускається, й елементів виробництва }\end{array}$ \\
\hline $\begin{array}{l}\text { 3. Технічні } \\
\text { чинники }\end{array}$ & $\begin{array}{l}\text { здійснювати роботу зі збільшення кількості винаходів і патентів, включаю- } \\
\text { чи вже запатентовані технології; } \\
\text { стежити за якістю виробленого товару з використанням сучасних методів } \\
\text { контролю }\end{array}$ \\
\hline $\begin{array}{l}\text { 4. Управлінські } \\
\text { чинники }\end{array}$ & $\begin{array}{l}\text { забезпечити можливість підвищення кваліфікації співробітників } \\
\text { підприємства; } \\
\text { за результатами діяльності підприємства формувати й упроваджувати } \\
\text { програми, спрямовані на розвиток і вдосконалення всіх процесів діяльності } \\
\text { підприємства; } \\
\text { здійснювати суворий контроль і організацію сировинних поставок, а також } \\
\text { матеріалів і комплектуючих виробів; } \\
\text { здійснювати внутрішню і зовнішню сертифікацію продукції і систем, тобто } \\
\text { систему управління якістю, яка в будь-якому разі повинна відповідати } \\
\text { міжнародним стандартам }\end{array}$ \\
\hline $\begin{array}{l}\text { 5. Ринкові } \\
\text { чинники }\end{array}$ & $\begin{array}{l}\text { регулярно вивчати основні зміни на ринку і моніторити ринкову інфра- } \\
\text { структуру; } \\
\text { мати доступ на ринки нових технологій; вживати заходів, спрямованих на } \\
\text { стабілізацію всіх конкурентних переваг із метою утримання лідируючого } \\
\text { положення на міжнародному ринку; } \\
\text { підвищувати рівень логістики і рівень кваліфікації маркетологів і праців- } \\
\text { ників збутової галузі; } \\
\text { вибирати тільки високопрофесійних співробітників реклами, а також сфор- } \\
\text { мувати окремий бюджет на рекламні цілі; } \\
\text { підвищувати ефективність системи стимулювання збуту }\end{array}$ \\
\hline $\begin{array}{l}\text { 6. Чинники } \\
\text { ефективності } \\
\text { функціонування } \\
\text { організації }\end{array}$ & $\begin{array}{l}\text { підвищувати науковий рівень управління; } \\
\text { відстежувати інтенсивність капіталу; } \\
\text { простежувати фінансову стійкість функціонування організації; підвищува- } \\
\text { ти ефективність використання всіх ресурсів із метою переважання частки } \\
\text { експорту наукомістких товарів }\end{array}$ \\
\hline
\end{tabular}

Джерело: складено автором на основі [ 3-5] 
Висновки. Отже, у сучасній боротьбі за місце на зовнішніх ринках недостатньо використовувати тільки цінові чинники. Необхідно активно впроваджувати переваги науково-технічного прогресу та підвищувати якість продукції.

Підводячи підсумок, необхідно відзначити, що компанія, яка бажає зміцнитися на міжнародному ринку, повинна дотримуватися хоча б більшої частини запропонованих заходів. Чим більше компанія матиме конкурентних переваг, тим вище ії конкурентоспроможність й ефективність на міжнародному ринку.

\section{Список використаних джерел:}

1. Касич А.О., Глущенко Д.О. Теоретичні та практичні аспекти управління конкурентоспроможністю підприємства. Економіка та держава. 2016. № 11. С. 65-70.

2. Михайленко О.В., Орлова К.Г. Система управління конкурентоспроможністю продукції підприємства. Науковий вісник Ужгородського начіонального університету. Серія «Міжнародні економічні відносини та світове господарство». 2017. № 13(2). С. 114-117.

3. Петрищева И.В. Особенности развития форм производственной кооперации различных предпринимательских структур. Народное хозяйство. Вопросы инновационного развития. 2011. № 1. C. 30-39.

4. Петрищева И.В. Синергический эффект при взаимодействии предприятий малого и крупного бизнеса. Инноваиионное образование и экономика. 2017. Т. 1. № 4. С. 87-89.

5. Скрябин О.О. Проблемы повышения конкурентоспособности малых предприятий. Молодой ученый. 2017. № 21. С. 473-475. URL: https://moluch.ru/archive/101/22912/ (дата обращения: 18.03.2021).

6. Терехов Д.С., Блідар О.В. Стратегічне управління конкурентоспроможністю підприємства. Наука й економіка. 2016. № 2. С. 76-80.

7. Янков О.Г. Теоретичні, метотодологічні та практичні аспекти конкурентоспроможності підприємств : монографія. Одеса : Атлант, 2017. 514 с.

\section{References:}

1. Kasych A.O., Glushhenko D.O. (2016) Teoretychni ta praktychni aspekty upravlinnya konkurentospromozhnistyu pidpryyemstva [Theoretical and practical aspects of enterprise competitiveness management]. Economy and state, no. 11, pp. 65-70.

2. Mykhajlenko O.V., Orlova K.Gh. (2017) Systema upravlinnja konkurentospromozhnistju produkciji pidpryjemstva [Enterprise product competitiveness management system]. Scientific Bulletin of Uzhhorod National University. Series: International Economic Relations and the World Economy, no. 13 (2), pp. 114-117.

3. Petrishheva I.V. (2011) Osobennosti razvitija form proizvodstvennoj kooperacii razlichnyh predprinimatel'skih struktur [Features of development of forms of production cooperation of various business structures]. National economy. Issues of innovative development, no. 1, pp. $30-39$.

4. Petrishheva I.V. (2017) Sinergicheskij jeffekt pri vzaimodejstvii predprijatij malogo i krupnogo biznesa [Synergistic effect in the interaction of small and large businesses]. Innovative education and economics, vol. 1, no. 4. pp. $87-89$.

5. Skrjabin O.O. (2017) Problemy povyshenija konkurentosposobnosti malyh predprijatij [Problems of increasing the competitiveness of small enterprises]. A young scientist, no. 21, pp. 473-475. Available at: https://moluch.ru/archive/101/22912/ (accessed 18 March 2021).

6. Terexov D.S., Blidar O.V. (2016) Strategichne upravlinnya konkurentospromozhnistyu pidpryemstva [Strategic management of enterprise competitiveness]. Science and economics, no. 2, pp. $76-80$.

7. Yankov O.G. (2017) Teoretychni, metotodologichni ta praktychni aspekty konkurentospromozhnosti pidpryemstv [Theoretical, methodological and practical aspects of enterprise competitiveness]. Odessa: Atlant. (in Ukrainian) 